\title{
Kamila Kulessa \\ Iluzje obecności. \\ Cielesność w Bez końca \\ Krzysztofa Kieślowskiego
}

\begin{abstract}
Kulessa Kamila, Iluzje obecności. Cielesność w Bez końca Krzysztofa Kieślowskiego [Illusions of presence. The body in Krzysztof Kieślowski's No end]. „Przestrzenie Teorii” 30. Poznań 2018, Adam Mickiewicz University Press, pp. 315-328. ISSN 1644-6763. DOI 10.14746/pt.2018.30.17.

This paper aims at providing an analysis of Krzysztof Kieślowski's film No end (1984), focused mainly on representations of corporality. The article attempts to interpret possible meanings of the phantasmatic dimension of existence and its impact on the reality constructed in the film. It also examines issues related to identification and the articulation of sensuous presence in cinematic images.
\end{abstract}

KEYWORDS: body, film, subjectivity specter

Studium nad postacią w czasie następującym po śmierci najbliższej dla niej osoby stwarza okazję do przyjrzenia się podmiotowi w całej jego kruchości, chwiejności, które wydobywa z niej graniczne doświadczenie. Potencjał tego tematu dla sztuki wielokrotnie wykorzystywany był przez twórców filmowych - tak stało się również w przypadku Krzysztofa Kieślowskiego, w zrealizowanym przez niego w 1984 roku filmie Bez końca. Rozważania o żałobie kierują nieuchronnie ku namysłowi dotyczącemu utraconego obiektu. Ze względu na szczególne strategie twórcze zastosowane w tym właśnie obrazie w podejmowanej analizie zastanawiać się będę nad miejscem, jakie zajmuje on w audiowizualnej narracji dzieła filmowego.

Pragnienie obecności męża Urszula, główna bohaterka filmu Kieślowskiego, odczuwa silniej niż miało to miejsce za jego życia. W rozmowie z przyjacielem zmarłego z czasów studenckich przyznaje, że niegdysiejszą bliskość z Antkiem odkryła na nowo we wcześniej nieodczuwanej pełni dopiero po jego nagłej, spowodowanej zawałem serca śmierci. Nieodwołalna utrata życiowego partnera rozbudziła w niej potrzebę przeżycia na nowo niedostrzeganej przez nią dawniej łączącej ich więzi. Swoista pośmiertna obecność jej męża o szczególnym statusie znajduje swój wyraz w jego ożywionym ciele, istniejącym na szczególnych prawach w świecie przedstawionym filmu. W przeprowadzanej analizie najbardziej interesujące będzie dla mnie właśnie pośmiertne ciało i sam jego status - próbuję zatem odczytać to, co wyraża cielesność nieżyjacego oraz to, w jaki sposób wpływa on na kreowaną w dziele rzeczywistość. 
To quasi-widmo ma dla mnie status ciała filmowego - może konkretyzować się jedynie dzięki dziełu filmowemu, w quasi-cielesnej postaci, reprezentując inną cielesność niż tradycyjnie definiowana w ontologii, w ujęciu której ciało traktowane jest jako integralna część człowieka jako psychofizycznej osoby ${ }^{1}$. Co istotne, to właśnie ludzkie ciało pozostaje tu nośnikiem znaczenia ${ }^{2}$, środkiem wyrażania, nawet jeśli jego fizyczność jest osłabiona niewidzialna, niedotykalna.

W Projekcie krytyki fantazmatycznej Maria Janion odtwarza romantyczny rodowód postaci niejasnych ontologicznie, których istnienie podważa nieprzekraczalność granicy pomiędzy fikcją a rzeczywistościa, a następnie prezentuje rozwój pojęcia fantazmatu w teorii Freuda i ujęciach pre- i postfreudowskich ${ }^{3}$. W swojej pracy będę posługiwała się pojęciem postaci fantazmatycznej, o wyobrażeniowym statusie, zastanawiając się nad miejscem, które zajmuje ona w realności świata przedstawionego. Fantazmatyczny czy wyobrażeniowy charakter może mieć jednak nie tylko ciało - taka jest również tworzona perspektywa widzenia mająca należeć do zmarłego, której znaczenie będę starała się zinterpretować.

Czasoprzestrzenie filmu Kieślowskiego pozostaja mimetyczne - okazuja się nierzeczywiste nie na poziomie wyglądów, ale należącego do widza rozpoznania prawdopodobieństwa opowiadanej historii. Odbiorca, świadomy tego, że akcja dzieła rozgrywa się po śmierci bohatera ukazywanego jako postać wyglądająca jak żywa, musi zrozumieć, że ożywa ona wyłącznie za sprawą dzieła filmowego, jako wyraz pewnych treści w zamyśle twórcy. Strategia ta kieruje uwagę $\mathrm{w}$ stronę panujących $\mathrm{w}$ rzeczywistości przedstawionej alternatywnych reguł istnienia, obnażając jej kreacyjny charakter ${ }^{4}$, ujawniając pęknięcie między światem przedstawionym a jego obrazem, leżące u samych podstaw tego ostatniego. Równocześnie nasuwać się mogą pytania o żyjących bohaterów, cielesność będąca nośnikiem ich podmiotowości. Skoro egzystują w czasoprzestrzeniach wspólnie z nieżyjąca postacia, jak należałoby określić ich status? Ostatecznie quasi-widmo na konstrukcyjnej płaszczyźnie obrazu tak samo jak oni pozostaje pełnowymiarowe, jest formalnym, graficznym bytem $^{5}$. Filmowy świat przedstawiony poprzez obecność zmarłego zostaje

${ }^{1}$ „Psychofizyczna struktura człowieka jest faktem naturalnym i w życiu ziemskim relatywnie trwałą kondycją człowieka, a dezinkarnacja jest niemożliwa”. S. Kowalczyk, Ciało człowieka w refleksji filozoficznej, Lublin 2009, s. 142.

${ }^{2}$ Nie będę zajmować się tu zatem post-ludzkim ciałem zautomatyzowanym, stechnicyzowanym ani cyborgiem, o których pisze m.in. Bogusława Bodzioch-Bryła w tekście Ku ciału post-ludzkiemu: o młodej poezji i nowej rzeczywistości, „Teksty Drugie” 2002, nr 6, s. 42-57.

${ }^{3}$ M. Janion, Projekt krytyki fantazmatycznej, [w:] tejże, Zto i fantazmaty. Prace wybrane, t. 3, Kraków 2001, s. 157-184.

${ }^{4}$ Zob. Z. Mitosek, Mimesis: zjawisko i problem, Warszawa 1997, s. 8.

${ }^{5}$ P. Kwiatkowska, Somatografia: ciało w obrazie filmowym, Kraków 2011, s. 32. 
naznaczony śmiercia, podważa tym samym pewność realnego istnienia żyjących. Interesujące wydaje się poszukiwanie w filmie oznak zrównywania różniących się od siebie ontologicznie bytów.

W narracji obecne są zatem strategie mające na celu łączenie ze sobą pośmiertnego i żyjących ciał za pomoca przedstawienia zmysłowego istnienia widma, nadawania mu pozorów realności, a tym samym i przenikania się świata rzeczywistego z tym, co nie mieści się w jego ramach. Przeważają tu zabiegi narracyjne dystansujące te różniące się od siebie byty - spotkanie z widmem jest bowiem dla żyjącego doświadczeniem nie tylko jego bliskości, ale i inności tego ontologicznie niepewnego istnienia. Wyobrażeniową postać w pewnym stopniu uobecnić może jednak skierowane na nią spojrzenie lub dotyk żywego. Dla interpretującego istotne staje się uchwycenie napięcia pomiędzy doznaniem bezpośredniej obecności a zupełną niemożnościąjej przeżycia.

Przedstawienie w obrazie filmowym tego rodzaju nieoczywistej cielesności umożliwia zatem wydobycie określonych możliwości rozszerzania wyrażeniowego potencjału ciała, na przykład wyrażania pragnienia namacalnego istnienia drugiej, nieobecnej czy zmarłej, osoby. Quasi-widmo ma zatem być między innymi środkiem do opowiadania o kondycji ludzkiej istniejących w rzeczywistości postaci, ich szczególnym statusie podmiotowym. Pośmiertny byt sygnalizuje, że bohaterka filmu Kieślowskiego postrzega własne ,ja” jako niepełne - poza sobą szuka podstawy dla określenia własnej tożsamości, w inny sposób spogląda na swoje działania, stwarza wyobrażeniowe obrazy samej siebie ${ }^{6}$. Relacja żyjącego i widma nie jest bynajmniej oczywista i jednostronna - te postacie o różnym statusie ontologicznym wchodzą ze sobą w wielopłaszczyznowe związki.

\section{Pęknięty obraz}

W recenzjach ukazujących się w prasie po premierze filmu w 1985 roku krytyka różnie reagowała na strategię Kieślowskiego, który zdecydował się na wprowadzenie do świata przedstawionego fantomowego ciała Antka? Nie zabrakło pytań o, jak się okazało, problematyczną konwencję, w której

${ }^{6}$ Do interpretacji statusu podmiotowego bohaterów, sposobów, w jaki ujmują oni własną tożsamość, służy mi koncepcja Lacanowskiej fazy lustra w interpretacji Pawła Dybla, zob. tegoż, Urwane ścieżki: Przybyszewski - Freud-Lacan, Kraków 2000, s. 237.

${ }^{7}$ Pozytywnie wyrażał się o filmie Tadeusz Sobolewski - w recenzji skupił się jednak, jak można się było spodziewać, na jego głównej bohaterce - w krótkim fragmencie poświęconym widmu, pisał jednak o znaczeniach, które wyrażać miała jego postać. „Jeśli więc adwokat po śmierci, której jesteśmy świadkami, nadal towarzyszy swojej żonie, trochę jak duch w japońskich filmach, czy jak zmarły ojciec w Fanny i Aleksander, oznacza to tylko tyle, że istnieje on nadal dla żony jako milczący świadek jej poczynań, wyrzut sumienia, milczące wspomnienie 
zrealizowane zostało Bez końca. Mirosław Przylipiak, który pośmiertny byt uznawał za zupełnie nieprzystający do kreowanej w filmie rzeczywistości, zastanawiał się nad uzasadnieniem obecności widma w filmie, który pozornie pozostaje wierny realizmowi ${ }^{8}$.

„Widmo" adwokata Zyro, prywatnie męża Uli, Antka, zostaje tu wyposażone w pewną sprawczość, możliwość ingerencji w świat przedstawiony filmu dzięki owdowiałej żonie. Jego działania należą do zobrazowanej sfery jej imaginacji - gdy bohaterka ogląda się w przeszłość, przypisuje zmarłemu mężowi swoje przeczucia co do podejmowanych przez siebie wyborów i wątpliwości, wręcz ustanawia go źródłem własnych niepokojów. Pośmiertne wyobrażenie Antka, będące projekcja świadomości Uli, uobecnia się $w$ ptaszczyźnie obrazu $u^{9}$, zyskując tu także własne ciało, staje się jednym z bohaterów filmu, konkretyzuje się w filmowo cielesnej postaci. Antek obserwowany przez widza pozostaje jednak przez większość trwania akcji niewidoczny dla bohaterów filmu, nie uczestniczy bezpośrednio w ich doświadczeniu. Wyjątek stanowią dwie sceny: sesji terapeutycznej, którą przechodzi Ula w mieszkaniu hipnotyzera, oraz rozgrywająca się na sali sądowej - bezpośrednio po zakończonej rozprawie siedzący w jednej z ławek dla publiczności Zyro zostaje dostrzeżony przez oskarżonego Darka, którego przed śmiercią reprezentować miał jako obrońca. Próbę ich interpretacji podejmę w dalszej części pracy.

\section{Sposoby widzenia}

Rozpoznania własnej podmiotowej niepełności Ula dokonuje także za pośrednictwem innych postaci. Równolegle do akcji skupionej wokół jej życia prywatnego w filmie rozwijany jest wątek oczekującego w areszcie na rozprawę sądową Darka. W dzień pogrzebu męża do bohaterki przychodzi z prośbą o pomoc żona oskarżonego, Joanna. Kobiety nawiązują bliższą relację, co staje się impulsem inicjującym ten proces wewnętrzny. To jednak widmo Antka, towarzyszace Uli nieustannie poczucie jego obecności sprawia, że Joanna staje się postacią mogącą wywierać wpływ na główną bohaterkę filmu. Urszula wydaje się zarazem przejmować część cech nieżyjącego - wrażli-

o kimś, kogo się nie dość kochało, kogo się zdradzało. Wreszcie jako obiekt tęsknoty”. T. Sobolewski, W samotności, „Kino” 1985, nr 222, s. 11.

8 „Film nastręcza pewne kłopoty z kwalifikacją gatunkowa. Coś jakby horror. Jest duch, cmentarz i czarny pies wprost z rekwizytorni Omenu". M. Przylipiak, Nie na temat, „Kino” 1986 nr 224, s. 8.

${ }^{9}$ Posługuję się definicją postaci zaproponowana przez Paulinę Kwiatkowska, która opisuje związki, w jakie wchodzą ze sobą trzy pojęcia tworzące w dziele filmowym ciag konstrukcyjno-interpretacyjny: aktor-postać-bohater, P. Kwiatkowska, dz. cyt., s.32. 
wego na ludzką krzywdę adwokata kierującego się współczuciem, świetnie rozumiejącego motywy działania i obecną trudność położenia Darka; chce go zastępczo reprezentować. To wyraźnie pamięć o zmarłym kieruje Ula, gdy podczas pierwszego spotkania z Joanna po krótkim namyśle zmienia decyzję i postanawia pomóc nieznajomej w sprawie dotyczącej jej męża.

Urszula postępuje bowiem tak, jak gdyby rzeczywiście była oglądana przez zmarłego, którego obecność wciąż silnie odczuwa - brak jego spojrzenia w świecie realnym sprawia, że chce być widziana w określony sposób przez żyjącą postać, jaka jest Joanna. Żona Darka przejmuje zatem pewien sposób patrzenia, przeniesiony na nią przez Urszulę. Szczególna jest zatem relacja tej drugiej z fantomowym spojrzeniem, którego wyrazem jest ciało zmarłego - wyobrażeniowy nośnik jego perspektywy uwewnętrznionej przez Ulę. Odczuwany przez nią lęk przed samotnością jest bowiem również lękiem przed wolnościa, samotnym życiem bez zobowiązań w stosunku do bliskich - bohaterka boi się utraty znaczenia, które nadawał jej status żony Antka, pomimo że żyła w jego cieniu, nieznana osobom, z którymi się stykał; przez cały czas chce czuć na sobie wzrok nieżyjącego, by wykreować na nowo swoją rolę życiową zależną od jego byłej pozycji.

Wzrok niewidzialnego dla innych Antka to przede wszystkim spojrzenie obserwujące, ogarniające pewien plan z dystansu. Już w pierwszych scenach filmu narracja wytwarza złudzenie, że widmowa postać może nim objać świat przedstawiony. Poranek po pogrzebie mecenasa Zyro Ula spędza nie tylko z synem Jackiem, ale także przy milczącej - odczuwalnej tylko dla niej - współobecności zmarłego męża. Niemożliwość pogodzenia się z jego nagłym odejściem powoduje, że w przeżywaniu żałoby nie dominuja przywoływane tylko z pamięci wspomnienia - jej życie napędza poszukiwanie w otaczającej ją rzeczywistości znaków istnienia zaprzeczających jego całkowitemu odejściu. Ula wydaje się sobie zbyt słaba, by samą siebie ochronić przed niebezpieczeństwem - przed wypadkiem drogowym ocala ja, o czym jest głęboko przekonana, interwencja Antka, w odpowiednim czasie doprowadzającego do awarii jej samochodu. Kiedy konieczne jest znalezienie następcy zmarłego, odpowiedniego adwokata dla oczekującego na rozprawę sądową Darka, Antek również „uczestniczy” w dokonywanym wyborze.

Osamotniona po śmierci Antka Urszulę definiuje w jej przekonaniu fakt bycia widziana - padające na nią spojrzenie widma męża ma dla niej jako podmiotu moc konstytuująca - jednak pragnienie spojrzenia tego właśnie innego jest przez nią zarazem konsekwentnie oddalane. Potrzebie jego istnienia towarzyszy podświadoma chęć jej wyparcia ze swojej świadomości - aż do sceny hipnozy, której poddaje się Ula: na pojawiające się kilkakrotnie widmo ani razu nie pada jej wzrok. Pośmiertne spojrzenie Antka jest nieodwzajemniane - jako filmowy środek wyrazu jego ciało pozostaje 
oczywiście niewidoczne dla bohaterki, ale na płaszczyźnie relacji pomiędzy postaciami niewidzialność widma dla Urszuli, brak porozumienia oznacza wypieranie pośmiertnej obecności męża z jej świadomości. Zobaczenie postaci, odsłonięcie Antka przed Ula, jest dla niej zatem konfrontacją z treścią własnego wnętrza. Śmierć męża oznacza zatem dla bohaterki konieczność refleksji nad swą tożsamością - utracone poczucie bezpieczeństwa sprawia, że musi ona na nowo przemyśleć swoje życie - dotychczasowe i obecne - by skonstruować nową o nim narrację i ustanowić ramy, w których możliwe będzie rozumienie własnej egzystencji.

\section{Pośmiertne ciało patrzące}

W filmie Kieślowskiego kreowana jest iluzja istnienia odrębnego punktu widzenia widma, które nie będąc realne, nie może jednocześnie stać się podmiotem fokalizującym narrację. Przedstawienie cmentarza pojawiającego się w poczatkowej scenie ma, jak okazuje się po chwili w kierowanej wprost do odbiorcy przedmowie Antka, pozorować ujęcie z jego perspektywy. W krótkim monologu przywołuje on wspomnienie własnej śmierci: umarłem cztery dni temu [...] wszystko widziatem trochę z góry, nawet się zdziwitem, że tak wszystko $z$ góry widać. Samo widmo nieżyjącego opisuje zatem doświadczenie, które, ze względu na ontologiczny status postaci, nie może należeć do niego. W rzeczywistości świat przedstawiony obejmuje swoim spojrzeniem Ula, a nadawanie pozorów realności widmu w ramach kreowanego uniwersum, tworzenie jego iluzorycznej perspektywy jest tu szczególną strategią twórcza. Na innej zaś płaszczyźnie to wyobrażone spojrzenie, nienależące do żadnego istniejącego bohatera, okazuje się mieć dla Urszuli, która nie może pogodzić się z całkowitym odejściem męża, konstytutywne znaczenie w późniejszych scenach filmu; początkowe ujęcia są zaś rodzajem wprowadzenia fantazmatycznego podmiotu uwewnętrznionego przez nią widzenia, służą swego rodzaju prezentacji quasi-widma i ustanowienia go jako postaci.

Nie tylko zmysł wzroku jest jednak dla Kieślowskiego wyrazem obecności bądź jej pragnienia. Również dłonie, jako związane z dotykiem, fizyczną bliskościa, są eksponowane w różnych scenach filmu, wyrażając zmysłową namacalność istnienia Uli w świecie przedstawionym. Bohaterka brudzi je, dotykając bezwiednie zabłoconej maski samochodu, a w rozmowie z Tomkiem, dawnym przyjacielem męża, bawi się, dziurawiąc palcami ukazane $\mathrm{w}$ bliskim planie rajstopy. Wreszcie zwraca uwagę na tę część ciała obcokrajowca, z którym przeżyje seksualne zbliżenie - ukazane w zbliżeniu ręce mężczyzny siedzącego samotnie przy kawiarnianym stoliku przypominają jej wyglądem ręce Antka (o czym napomyka w rozmowie z Tomkiem). Bo- 
haterka, odczuwając potrzebę jego cielesnej obecności, przenosi niemożliwe do spełnienia pożądanie nieobecnego na nieznajomego mężczyznę, a jej pragnienie zostaje rozbudzone przez fizyczne podobieństwo między nimi. Już nie wzrok, ale właśnie dotyk staje się tu źródłem doznania obecności i zaspokojenia jej uświadomionego pragnienia - padajace zawsze z dystansu spojrzenie Antka nie może bowiem być, w sposób boleśnie dojmujący dla Urszuli, przez nią odwzajemnione.

Samo filmowe ciało Antka wchodzi w jednostronną relację ze światem przedstawionym właśnie za pośrednictwem spojrzenia, projekcja jego rąk zostaje jednak wyeksponowana w jego widzialnej dla bohaterki postaci. W scenie jej hipnozy widmo zmarłego męża trzyma w rękach szklankę, której pocieranie palcem wywołuje charakterystyczny przenikliwy dźwięk. Sfera audialna urealnia pośmiertna obecność i działanie Antka w świecie Uli, choć widz ma do czynienia z wyraźnym cudzysłowem stworzonym przez hipnotyczną ramę tej sceny, rozgrywającej się w gabinecie psychoterapii ${ }^{10}$. Małżonkowie powtarzają kolejno po sobie gesty rąk tak, że nie sposób jednoznacznie ustalić, które z nich naśladuje ruchy drugiego. Dłonie, nie tylko oznaczajace zmysł dotyku, wprowadzają wyraziste zaprzeczenie dystansu, a jednak Ula i tutaj nie doświadczy pełnej obecności męża. Jedynie te dwie postacie bowiem porozumiewają się za pośrednictwem gestów angażujących ręce, które, owszem, sa, zastępczo, znakiem bliskości, nie moga jednakże w ich świecie wyrażać jej bezpośrednio poprzez wzajemny dotyk; ruchy rąk fantazmatycznego ciała Antka odbiera więc bohaterka jedynie z oddalenia. Kieślowski podejmuje zatem grę z konwencjonalnymi znaczeniami ciał postaci. Ręce wyrażają tradycyjnie porozumienie, pamięć obrazu i dotyku ciała, a przede wszystkim łączą się z fizycznym uobecnieniem. We wspomnianej scenie hipnozy dopełniające się zmysły zostają sobie tymczasem w pewnym stopniu przeciwstawione. Widmo Antka zaczyna istnieć zmysłowo dla bohaterki - jej wzrok dostrzega obraz zmarłego, a widzialne gesty mają moc urzeczywistniająca jego postać, wciąż są to jednak dłonie niedotykające, porozumiewające się na dystans.

Zanim jednak Ula zobaczy Antka podczas sesji hipnozy, jest on niewidzialnym dla pozostałych bohaterów ciałem. Wzrok skierowany na niego

${ }^{10}$ Bogusławski pisze o idei intersensualności, która ma być „papierkiem lakmusowym pozwalającym na odróżnienie tego, co realne, od tego, co urojone. Jedność zmysłów umożliwia mówienie o jednolitej świadomości świata, ponieważ pozwala na komplementarne traktowanie jakości zmysłowych oraz na dostrzeżenie ekwiwalentności tych wrażeń”. M.M. Bogusławski, Czy potrzebujemy ontologicznej refleksji nad ciałem?, „Prace Kulturoznawcze” 2012, nr 14, s. 60. Świat przedstawiony w Bez końca okazuje się zbudowany na innych zasadach - różnorodne dane percepcyjne mogą zaprzeczać sobie nawzajem, zmysły nie oferują możliwości ostatecznego rozstrzygania o rzeczywistym bądź imaginatywnym charakterze zjawisk. 
przez żonę decyduje o zmianie jego statusu - powoduje rozdwojenie tego ucieleśnionego bytu na poziomie widzialności. Zyro pojawia się zatem w filmie w dwóch różnych postaciach, dwóch modalnościach: dla Uli zarówno niematerialnie - jako wspomnienie, odczucie, jak i w cielesnej postaci - jako doświadczenie obecności fantazmatycznego, widzialnego już ciała. Zobaczenie Antka przez Urszulę oznacza na tej płaszczyźnie zmniejszenie czasoprzestrzennej rozbieżności między nimi. W obrazie dokonuje się jednak istotne rozwarstwienie. Twarzysząca bohaterce podczas wizji postać hipnotyzera, zaświadczająca, iż Antek nie jest już obiektywnie istniejącym bytem, wprowadza częściowy dystans do widzenia Uli, podczas gdy ona sama staje się $\mathrm{w}$ tej scenie postacią fokalizująca obraz ${ }^{11} \mathrm{i}$ uobecnienia go za pośrednictwem spojrzenia w subiektywnej realności świata przedstawionego.

\section{Identyfikacje}

Przedstawienie ciała-widma, o nieuchwytnej powierzchownej cielesności, mającej odzwierciedlać jego szczególny status jako postaci, wymaga szczególnych strategii twórczych. Ciało nieżyjącego Antka w pierwszej scenie filmu ukazywane jest w kadrze fragmentarycznie - pojawia się jego ręka zawieszona nad śpiącym synem, wykonująca z oddalenia gest gładzenia go po głowie, ukazuje się jako odbicie w przeszkleniu komody. Filmowe ciało $\mathrm{w}$ tych początkowych ujęciach przedstawiane jest jako niezależne od pozostałych elementów kreowanej w dziele rzeczywistości - dłon Antka ukazuje się w jednym z nich w pokoju Jacka w pełnej ostrości, na tle zanikających konturów przedmiotów znajdujących się na dalszym planie. Figura zmarłego męża staje się lustrem dla Uli, która, odczuwając jego obecność, postrzega siebie w odmienny sposób - pragnienie połączenia ze zmarłym zmienia jej własne widzenie i samopostrzeganie. Metafora zwierciadła wyraża ponadto powierzchniowy, niepełnowymiarowy charakter jego istnienia. Na postać widma Antka Urszula projektuje swoje pragnienia i lęki - jest on bytem pozbawionym samoistnej esencjonalności, wypełnianym treścią nadaną mu przez bohaterkę. Obraz widzialnego dla Urszuli Antka pochodzi częściowo $\mathrm{z}$ otaczającego ja świata realnego, co ukazane zostaje w scenie nieudanej hipnozy: czynność obrysowywania krawędzi szklanki palcem przez mężczyznę wprowadzającego w stan transu wykonuje podczas pierwszej wizyty w jego mieszkaniu fantomowe ciało jej męża - narracja tworzy zatem pomosty pomiędzy rzeczywistościa istniejąca obiektywnie oraz wewnętrznym światem protagonistki. Małżonkowie w pewnym sensie również stają się

${ }^{11}$ M. Bal, Narratologia: wprowadzenie do teorii narracji, przekład zespołu tłumaczy ze specjalizacji przekładowej Instytutu Filologii Polskiej UAM w Poznaniu, Kraków 2012, s. 147. 
w tej scenie wzajemnymi odbiciami - powtarzają po sobie gesty rak, posługując się jedynie dla nich zrozumiałym wizualnym kodem. Przeglądając się $\mathrm{w}$ fantazmatycznym innym, bohaterka pragnie osiagnaćc (choćby iluzoryczna) pełnię istnienia - patrzące ciało Antka wydaje się ustawionym przez twórcę lustrem, które zmusza ją do skonfrontowania się z samą soba, z własną tożsamością.

Pośmiertna obecność męża jest zatem dla Urszuli szczególnym punktem odniesienia. Z jednej strony wspomnienie o nim umożliwia jej ustanowienie własnej tożsamości - poprzez dokonywanie konkretnych wyborów bohaterka jako wdowa po adwokacie może w określony sposób zobaczyć samą siebie. Postać Antka staje się dla Uli lustrem, rodzajem płaszczyzny, na którą rzutuje ona własny obraz i ulega jego iluzji ${ }^{12}$. Nie oznacza to jednak jedynie bezwarunkowego poddania się jego - obrazu - twórczej sile ${ }^{13}$. Ula nie zyskuje nad pośmiertnym bytem pełnej kontroli - poza tym, że jest on wyrazem jej spojrzenia na siebie, zwrotu ku sobie, staje się równocześnie miejscem, z którego Ula jest widziana - jest zatem ucieleśnieniem zewnętrznego spojrzenia ${ }^{14}$, nietożsamego z perspektywą bohaterki. Ucieleśniony byt Antka uczestniczy zatem w jej wyobrażeniowej identyfikacji, która, jak pisze Zizek, dokonuje się zawsze ze względu na spojrzenie Innego ${ }^{15}$, która zawsze nieuchronnie naznaczona jest identyfikacją symboliczną i przez nią zdominowana ${ }^{16}$. Pośmiertne ciało staje się wobec Uli dwuznaczne - umożliwia konstruowanie własnej tożsamości i wprowadza w nią dystans, prowadzi $\mathrm{ku}$ autoalienacji.

\section{Natura fantazmatu}

Widmo Antka uobecnia się jednak nie tylko w scenach związanych bezpośrednio z Urszula. Jego obecnościa, choćby pozbawioną ciała, przesycony jest niemal cały świat przedstawiony filmu - przez krótką chwilę widzi go Darek, choć wcześniej zjawia jako jeszcze niewidoczny dla bohatera w jego celi. Uobecniany jest jednak nie tylko przez padające na jego postać spojrzenie żony czy przebywającego $\mathrm{w}$ areszcie mężczyzny. W rzeczywistym świecie pojawiają się materialne znaki jego obecności: w czasie poszuki-

${ }^{12}$ Owa iluzja imago nie może bowiem istnieć poza tym, co wypiera [...]. P. Dybel, Samouwiedzenie w lustrze, „Przegląd Filozoficzny” 1996, nr 4, s. 13.

${ }^{13}$ H. Lang, Język i nieświadomość, tłum. P. Piszczatowski, Gdańsk 2005, s. 75.

${ }^{14}$ S. Žižek, Wzniosty obiekt ideologii, tłum. J. Bator, P. Dybel, Wrocław 2001, s. 131.

${ }^{15}$ Tamże, s.132 i dalej: W odniesieniu do każdej imitacji wyobrażenia wzorcowego, do wszelkiego „odgrywania roli”, należałoby zatem postawić pytanie: dla kogo podmiot odgrywa rolę? Czyje spojrzenie wchodzi w grę, gdy podmiot identyfikuje się z jakimś wyobrażeniem?

16 Tamże, s. 135. 
wań zastępczego obrońcy dla Darka narysowany czerwonym flamastrem znak zapytania w spisie adwokatów, który Ula odczytuje jako wskazówkę od zmarłego męża („Antek napisał, żeby nie Labrador”), upadający nagle zegarek Labradora w rozgrywającej się $\mathrm{w}$ gmachu sądu scenie rozmowy z Joanna - prezent od Antka, którego niewidzialną dla bohaterów postać widz zauważyć może po chwili przechadzającą się korytarzem. Gdy znika „Trybuna Ludu” przyniesiona przez Joannę zastępującemu męża Uli adwokatowi, widz domyśla się już, że została „skradziona” przez widmo zmarłego. Te ukazujące się kilkakrotnie znaki widzialne są zatem również dla innych bohaterów poza Ulą i Darkiem, jego obecność wyraźnie wyczuwa także pies Zyrów.

Zastanawiać może wreszcie także obraz ciała samego przebywającego w areszcie Darka, odgrodzonego od świata zewnętrznego, ograniczonego jedynie do kontaktów ze swoimi obrońcami. Z rozmowy prowadzonej z zastępującym zmarłego adwokatem, Labradorem, widz dowiaduje się o wewnętrznym pokrewieństwie łączącym oskarżonego z Antkiem, ich wzajemnym porozumieniu w kwestii linii obrony podejrzanego podczas rozprawy. W przeciwieństwie do mecenasa Zyro, nieodbiegającego wyglądem od żywych bohaterów, izolowany od świata Darek wygląda jak zjawa, zaczyna jakby żyć na krawędzi dwóch światów, pograniczu rzeczywistości zawężonej do przestrzeni celi i rzadkich odwiedzin, a z drugiej strony coraz intensywniejszego życia wewnętrznego, wspomnień i rojeń wyobraźni. W scenie rozmowy z Labradorem po rozpoczęciu strajku głodowego zjawiskowo blada twarz i intensywnie niebieskie oczy wycieńczonego bohatera wyróżniają go na tle innych postaci. $\mathrm{W}$ tym stanie również on, jako jedyny poza Urszula, widzi widmo Antka, tym razem zasiadające w ławie na sali sądowej - uobecnione $\mathrm{w}$ quasi-ciele, urzeczywistnione przez spojrzenie oskarżonego, po raz drugi, tym razem dla mężczyzny, zjawiające się w kadrze pod postacią inną niż niewidoczne dla wszystkich żyjących ciało. Widzialność zmarłego dla bohatera włącza widmo do specyficznie własnej czasoprzestrzeni Darka, oddalając go na chwilę od rzeczywistości świata przedstawionego. Dotyka go zatem inny rodzaj odcieleśnienia - przez rodzaj pewnego odczłowieczenia - jego sponiewierana fizyczność przyjmuje wygląd zjawy za życia, podczas gdy pośmiertne ciało Antka wizualnie nie przypomina widma. Mąż Joanny naznaczony zostaje widmowością o zupełnie innym niż poprzednio wymiarze, wskazujący na nieoczywistość jego wizualnej kreacji, sugerując znów problematyczny status ontologiczny postaci.

Pośmiertne ciało Antka nigdy nie jest dla Uli w pełni uchwytne. Jego postać pozostaje dla bohaterki niewidoczna lub przynajmniej niedotykalna, nie podporządkowuje się całkowicie jej pragnieniu, bywa również, że - jak we wspomnianej scenie rozgrywającej się w celi - dzieli ją od quasi-widma 
czasoprzestrzenny dystans. Twórcza siła wyobraźni oddziałuje tu poza ściśle wytyczonym horyzontem subiektywności. Fantazmatyczny Antek wymyka się w pewien sposób jej imaginacji, tracącej pełnię kontroli nad obrazami, które sama projektuje ${ }^{17}$. W znaczeniu psychoanalitycznym projekcja jest bowiem wysyłaniem na zewnattrz obrazu tego, co istnieje w podmiocie w sposób nieświadomy ${ }^{18}$, co - na co wskazują Laplanche i Pontalis - zbliża to pojęcie do stosowanego w kinematografii. W przypadku fantazmatycznej filmowej postaci oznaczać będzie także swego rodzaju powoływanie do życia bytu, który ucieleśniając się w widzialnej formie, przekracza subiektywność, w pewnym stopniu uniezależnia się od niej, chociaż pozostaje nią naznaczone, stając się unaocznieniem tego, co Deleuze, opisując kino po modernistycznym przełomie, nazywa „mową pozornie zależną”, „pozornie zależną subiektywnością ${ }^{19}$.

Ostatnia scena filmu przedstawia wydarzenia rozgrywające się już po rozprawie sądowej. Składające się na nią ujęcia ukazują Ulę, która wykonuje w mieszkaniu kilka ostatnich czynności przed śmiercia, a następnie popełnia samobójstwo. Bohaterka Bez końca decyduje się na opuszczenie ciała, w którym po odejściu Antka czuje się obco, jakby jej tożsamość została okaleczona, „wybrakowana”, pozbawiona istotnej czastki „ja”. Scena ta dzieli się na dwa segmenty - w jej drugiej części ukazane zostaje wyobrażone przez Urszulę zjednoczenie małżonków po jej śmierci. W jej imaginacji urzeczywistnia się teraz całkowicie pragnienie zespolenia z mężem, w dotyku jego ciała spełniona zostaje potrzeba fizycznej bliskości. Podczas gdy za ich życia pełnia współbycia nie zawsze była możliwa, w wyobrażeniu Uli dokonującej zamachu na swe życie jej własny pośmiertny byt jest jedyna możliwością połączenia z pośmiertnym bytem Antka - w fantazmatycznej czasoprzestrzeni małżonkowie mogą przebywać wspólnie na takich samych prawach, zostaja ze sobą zrównani. W obrazie ukazane zostają obydwie postacie, z perspektywy bohaterki już ze sobą zjednoczone - ich wizerunki odbijaja się w wewnętrznej ścianie w głębi piekarnika, przed którym we wcześniejszym ujęciu siedzi skulona umierająca kobieta. Perspektywę Uli unaocznia wyrazista w tym obrazie rama: prostokąt otwartego piekarnika, którego czeluść staje się dla niej drogą ku Antkowi, „na drugą stronę życia”. To zwizualizowane wyobrażenie bohaterki, oddzielonej teraz od własnego ciała; jej odejście z mężem jest widzialne dla widza poprzez szybę, odcina-

${ }^{17}$ Zob. J. Starobiński, Wskazówki do historii pojęcia wyobraźni, tłum. W. Kwiatkowski, „Pamiętnik Literacki” 1972, nr 4, s. 222.

${ }^{18}$ J. Laplanche, J.-B. Pontalis, Stownik psychoanalizy, tłum. E. Modzelewska, E. Wojciechowska, Warszawa 1996, s. 250.

${ }^{19}$ G. Deleuze, Kino. 1. Obraz-ruch. 2. Obraz-czas, tłum. J. Margański, Gdańsk 2008, s. 372 . 
jąca ich jak gdyby od realnego świata ${ }^{20}$, od zatrutego śmiertelnie ciała Uli pozostałego przed kuchenka gazowa.

W kontekście wyobrażeń istotny okazuje się także wielokrotnie wykorzystywany tu środek wyrazowy - spojrzenie w kamerę, które ma dwa, mogłoby się wydawać, wykluczające się znaczenia: jako środek doprowadzający do zburzenia czwartej ściany jest środkiem deziluzji, ale równocześnie ma charakter iluzyjny. Wzrok nieżyjącego Antka skierowany w stronę widza ma zaświadczać o jego realnym - możliwym do bezpośredniego doświadczenia - istnieniu, tworzyć pozory pełni jego bycia jako podmiotu. Swoją przedmowę w pierwszej scenie filmu - jako byt niedostępny spojrzeniu Urszuli - kieruje wyraźnie w stronę widza, a nie którejkolwiek z postaci, co podkreśla tylko stopień jego uniezależnienia od świata przedstawionego. Również Urszula w jednej ze scen spogląda wprost na widza. Zarówno zatem w pierwszej sekwencji filmu widmo mężczyzny, jak i kobieta zapalająca znicz na grobie męża, wypowiadają słowa kierowane w stronę kamery. Narracja kreuje zatem iluzję ich wzajemnego porozumienia, wyróżniając ich spośród innych postaci, mimo że tylko bohaterka, wyznając miłość do męża, zwraca się do niego w wyraźny sposób. Współistnienie Uli i Antka $\mathrm{w}$ jednej czasoprzestrzeni jest równoznaczne ze zderzeniem w niej dwóch różnych rodzajów cielesności - spojrzenie postaci w kamerę, jako wspólne dla głównej bohaterki i pośmiertnego ciała jej męża staje się wyrazem zrównania statusu ich bytów, odzwierciedlając wyobrażone przez Urszulę współbycie z bliskim zmarłym.

To połączenie z Antkiem pozostaje jednak iluzją, doświadczeniem, które możliwe staje nie tylko pomimo jego śmierci, ale również, a może przede wszystkim, dzięki niej. Dopiero wtedy bowiem, gdy Zyro staje się quasi-widmowym ciałem, fantazmatycznym bytem - a więc przynajmniej do pewnego stopnia podległą bohaterce projekcja - Ula może wypełnić go własnym pragnieniem ${ }^{21}$. Zgodnie z natura fantazji zostaje przedstawione w niej nie tylko to, co najbardziej pożądane, lecz także to, co odsuwane przez podmiot a więc wypierana, skrywana przez Ulę niemożliwość bliskości za życia męża. Jak przypomina Žižek, sama fantazja jest „pierwotnym kłamstwem "22. Takim jednak kłamstwem, któremu udaje się zawładnąć Ulą całkowicie. Chociaż jej spojrzenie skierowane na Antka jest wyrazem przyjęcia jego pośmiertnej

${ }^{20} \mathrm{~W}$ tej scenie zespolenia po śmierci obydwu postaci Antek zwraca się z powitaniem wprost do Uli, swoje spojrzenie kierując w stronę obiektywu - podobnie bohaterka, wyznając miłość mężowi przy grobie zmarłego, również patrzyła prosto w kamerę.

${ }^{21} \mathrm{Na}$ takich zasadach oparta jest, jak pisze Lang, relacja z innym w opisanej przez Lacana intersubiektywności wyobrażeniowej: „[...] zniwelować inność Ty, by stopić się razem z nim w iluzoryczną jedność”, H. Lang, dz. cyt., s. 81.

${ }^{22}$ S. Žižek, Przekleństwo fantazji, tłum. A. Chmielewski, Wrocław 2001, s. 34. 
obecności jako integralnej części własnego życia, rodzajem autodiagnozy, ten istotny zwrot równoznaczny jest z pograzżeniem się bohaterki w iluzji, przyjęciem reguł istnienia narzucanych jej przez sam fantazmat. We własnym wyobrażeniu Ula nie może pozostać żywa, aby urzeczywistnić pełnię wspólnego bycia z mężem - to poddanie się iluzyjnej sile prowadzi ostatecznie do jej samobójczej śmierci.

Obecność fantazmatycznej postaci w obrazie filmowym generuje i uwypukla zatem relacje oparte na międzypodmiotowości i międzycielesności. Status pośmiertnego bytu Antka, wykraczający poza granice subiektywnej wizji, pozostaje w swojej specyficznej cielesności nieredukowalny jedynie do wytworu napędzanej przez pragnienie jego obecności wyobraźni bohaterki. Także bowiem jej cielesność istnieje - w tej wzajemnej relacji - w złączeniu w tym, co przez quasi-widmo upostaciowione. Zaangażowanie różnorodnych narzędzi analityczno-interpretacyjnych pozwala uzmysłowić nieprzejrzystość tego istnienia - niedającego się w pełni ujarzmić i sprowadzić jedynie do „pustej” cielesnej powłoki czy odcieleśnionego spojrzenia. W ramach filmowego uniwersum pozostaje ono ciałem, mimo że funkcjonującym na odmiennych prawach. To pośmiertne ucieleśnienie w obrazie Kieślowskiego niewątpliwie wymyka się jednoznacznym konceptualizacjom. Wybór tej strategii twórczej ma zatem szczególne konsekwencje - także to, co poza granicami pojedynczego ciała naznaczone zostaje widmowym wymiarem istnienia.

\section{BIBLIOGRAFIA}

Bal M., Narratologia: wprowadzenie do teorii narracji, przekład zespołu tłumaczy ze specjalizacji przekładowej Instytutu Filologii Polskiej UAM w Poznaniu, Kraków 2012.

Bodzioch-Bryła B., Ku ciału post-ludzkiemu: o młodej poezji i nowej rzeczywistości, „Teksty Drugie" 2002, nr 6, s. 42-57.

Bogusławski M.M., Czy potrzebujemy ontologicznej refleksji nad ciałem?, „Prace Kulturoznawcze" 2012 , nr 14, s. 55-68.

Deleuze G., Kino. 1. Obraz-ruch. 2. Obraz-czas, tłum. J. Margański, Gdańsk 2008.

Dybel P., Samouwiedzenie w lustrze, „Przegląd Filozoficzny” 1996, nr 4, s. 7-18.

Dybel P., Urwane ścieżki: Przybyszewski - Freud - Lacan, Kraków 2000.

Janion M., Projekt krytyki fantazmatycznej, [w:] M. Janion, Zło i fantazmaty. Prace wybrane, t. 3, Kraków 2001, s. 157-184.

Kowalczyk S., Ciało człowieka $w$ refleksji filozoficznej, Lublin 2009.

Kwiatkowska P., Somatografia: ciało w obrazie filmowym, Kraków 2011.

Lacan J., Stadium zwierciadła jako czynnik kształtujacy funkcję ja, w świetle doświadczenia psychoanalitycznego, tłum. J.W. Aleksandrowicz, „Psychoterapia” 1987, nr 4 , s. 5-9. 
Lang H., Język i nieświadomość, tłum. P. Piszczatowski, Gdańsk 2005.

Laplanche J., Pontalis J.-B., Projekcja, [w:] Stownik psychoanalizy, tłum. E. Modzelewska, E. Wojciechowska, Warszawa 1996, s. 246-252.

Markowski M.P., Pragnienie obecności. Filozofie reprezentacji od Platona do Kartezjusza, Gdańsk 1999.

Mitosek Z., Mimesis: zjawisko i problem, Warszawa 1997.

Przylipiak M., Nie na temat, „Kino” 1986, nr 224, s. 8-10.

Rembowska-Płuciennik M., Poetyka intersubiektywności. Kognitywistyczna teoria narracji a proza XX wieku, Toruń 2012.

Sobolewski T., W samotności, „Kino” 1985, nr 222, s. 10-13.

Starobiński J., Wskazówki do historii pojęcia wyobraźni, tłum. W. Kwiatkowski „Pamiętnik Literacki” 1972, nr 4, s. 217-232.

Žižek S., Przekleństwo fantazji, tłum. A. Chmielewski, Wrocław 2001.

Žižek S., Wzniosły obiekt ideologii, tłum. J. Bator, P. Dybel, Wrocław 2001. 